\title{
EVALUATION OF TOTAL ORGANIC CARBON QUANTITY AND EMISSIONS OF CO 2 FROM SOIL INTO THE ATMOSPHERE NEAR STREET
}

\begin{abstract}
Soil as an ecosystem is actively involved into climate formation process. Therefore, it is important to assess such soil quality indicators as total organic carbon (TOC) and $\mathrm{CO}_{2}$ emissions. Soil organic matter is considered to be its indicator of quality, which is one of the most important components of biosphere consistency and stability. Soil respiration shows carbon emission from soil into the atmosphere. This is a great indicator, illustrating soil biological activity. Impact of soil temperature, air humidity, time of day was evaluated on $\mathrm{CO}_{2}$ emission from the soil. The highest $\mathrm{CO}_{2}$ emission is observed in afternoon hours, up to $0.201 \mathrm{~g} \mathrm{CO}_{2} \cdot \mathrm{m}^{-2} \cdot \mathrm{h}^{-1}$.
\end{abstract}

Keywords: total organic carbon, heavy metals, $\mathrm{CO}_{2}$ emission, polluted soil

\section{Introduction}

One of the most important environmental problems is soil degradation related with soil pollution. It is especially evident in industrial and commercial areas as well as near intensive traffic roads. In recent years climate change issues are still one of the most relevant issues when dealing with problems of anthropogenic activities. Soil as an ecosystem is actively involved into climate formation process. When under the sway of spheres around it, this ecosystem accumulates large carbon reserves and after oceans is the second biggest carbon source in the world. The soils of EU-27 Member States are estimated to store round 73 to $79 \cdot 10^{15} \mathrm{~g}$ (billion tonnes) of carbon, which is more than 50 times the anthropogenic emissions of the 27 Member States of the European Union in 2009 year [1]. An especially dramatic growth in the $\mathrm{CO}_{2}$ emission from pollution sources occurred after 1956 , reaching the value of $36.8 \mathrm{Pg} \mathrm{CO}_{2} / \mathrm{yr}$ in 2017 [2]. Air pollution is considered as one of the main factors affecting the health of the population. It can cause negative changes in the respiratory and circulatory systems, even when concentrations do not exceed permissible levels. The most dangerous pollutants are $\mathrm{NO}_{2}$, ozone, PM10 [3]. $\mathrm{CO}_{2}$ is not very dangerous to human health but increasing emission of $\mathrm{CO}_{2}$ is related to global warming effect. Average global temperature is higher by $0.8{ }^{\circ} \mathrm{C}$ when compared to pre-industrial levels. In order to avoid the adverse effects of irreversible climate change, global temperature must not rise more than $2{ }^{\circ} \mathrm{C}$ [4]. The high amount of carbon dioxide has raised an urgent problem [5]. Road traffic is associated with emissions of many known hazardous and toxic substances. These include heavy or trace metals, polycyclic aromatic

\footnotetext{
${ }^{1}$ Environmental Protection and Water Engineering Department, Faculty of Environmental Engineering, Vilnius Tech, Vilnius, Saulètekio ave. 11, Lithuania, phone +370 52744725

*Corresponding author: dainius.paliulis@ vilniustech.lt
} 
hydrocarbons, volatile organic compounds (VOCs) and de-icing salts, which are emitted by motor vehicles and road infrastructure. The following metals: Ag, Al, As, Ba, Ca, Cd, Co, $\mathrm{Cr}, \mathrm{Cu}, \mathrm{Fe}, \mathrm{Hg}, \mathrm{Mn}, \mathrm{Mo}, \mathrm{Ni}, \mathrm{Pb}, \mathrm{Pd}, \mathrm{Pt}, \mathrm{Rh}, \mathrm{Sb}, \mathrm{Se}, \mathrm{Sr}, \mathrm{V}, \mathrm{Zn}$ are among the road traffic contaminants [6]. In roadsides, especially alongside busy highways, heavy metals are accumulated. Consequently, it is very important to evaluate what is soil pollution impact on soil quality indicators - TOC and $\mathrm{CO}_{2}$ emissions from soil. Scientific and statistical studies state that controlling soil respiration and carbon (C) cycling are of particular interest because soils contain twice as much $\mathrm{C}$ as the atmosphere and three times as much as vegetation [7]. Unlike the atmosphere, soil air composition is very dynamic. An indicator of soil respiration and biological activity is $\mathrm{CO}_{2}$ emission speed per time unit from a soil area unit, which, according to various soil, varies from 0.01 to $1.5 \mathrm{~g} \cdot \mathrm{m}^{-2} \cdot \mathrm{h}^{-1}$ [8]. Soil respiration indicates carbon emission from soil into the atmosphere. This is a great indicator, illustrating soil biological activity [9]. When soil organic matter decays, carbon dioxide $\left(\mathrm{CO}_{2}\right)$ is produced into the atmosphere, and otherwise - when organic matter is formed, $\mathrm{CO}_{2}$ is removed from the atmosphere. Carbon dioxide, which is produced from soil, contributes to the overall balance of $\mathrm{CO}_{2}$, which contributes to climate warming. When temperature is increasing, soil organic matter decays more rapidly, and for this reason their reserves decline. This is a reason for soil degradation process. Soil fertility depends on soil organic matter quantity and it has an impact to plants [10]. Soil carbon is a key chemical element of soil fertility, which plays the main role in processes of ecosystem such as water retention process. Therefore, the existing carbon sources must be protected and expanded. Soil organic matter is held to be its quality indicator, which is one of the most important elements of biosphere permanence and stability [11]. Not all carbon is immobilized in soil, which is accumulated in ecosystems. When plants breathe and micro-flora dissociates plant remnants and soil organic carbon turns to $\mathrm{CO}_{2}$ and $\mathrm{CH}_{4}$ gas, a part of carbon is returned into the atmosphere. Organic carbon compounds which are melted in soil solution can be washed into the ground-waters. For this reason, when $\mathrm{C}$ sequestration and the intensity of metabolism in ecosystems is evaluated, these $C$ losses are assessed [12]. One of the major tasks related to climate change is to rise carbon sequestration (accumulation) in ecosystems [13]. Many scientists studied $\mathrm{CO}_{2}$ emission from soil [14-26]. The present challenge to soil science is to present such knowledge in order to prudently avoid dangerous areas and take measures in order to keep soil vitality and its main functions. Consequently, in order to better understand and assess the possibility of greenhouse gas emission reduction, produced by soil, soil organic matter decline, it is necessary to collect and analyse such data. In this work the total organic carbon quantity in soil was evaluated applying dry sample combustion in high temperature method and $\mathrm{CO}_{2}$ emission from soil was evaluated applying infrared light camera. The main objective of this work was to evaluate the state of polluted street soil in accordance with such indicators as total organic carbon quantity and $\mathrm{CO}_{2}$ emission from soil which is affected by sources of an anthropogenic pollution activities.

\section{Materials and methods}

Galvè street in Vilnius was selected for experimental research where average traffic intensity is about 1600 vehicles per hour according to data of Lithuanian Road Administration under the Ministry of Transport and Communications. The research was conducted in two sections, perpendicularly to street, at both sides of road in the road section 
located in Paneriai forest in Vilnius city municipality. At both street sides, as far as possible in the direction perpendicular to used section, measured areas were chosen, which place from the equal stretch may deviate due to improper boring surface - thickly overgrown areas of bushes. At both street sides were selected 3 research areas. In overall, experimental research consisted of six measurement cells (A, B, C, D, E, F) (Fig. 1).

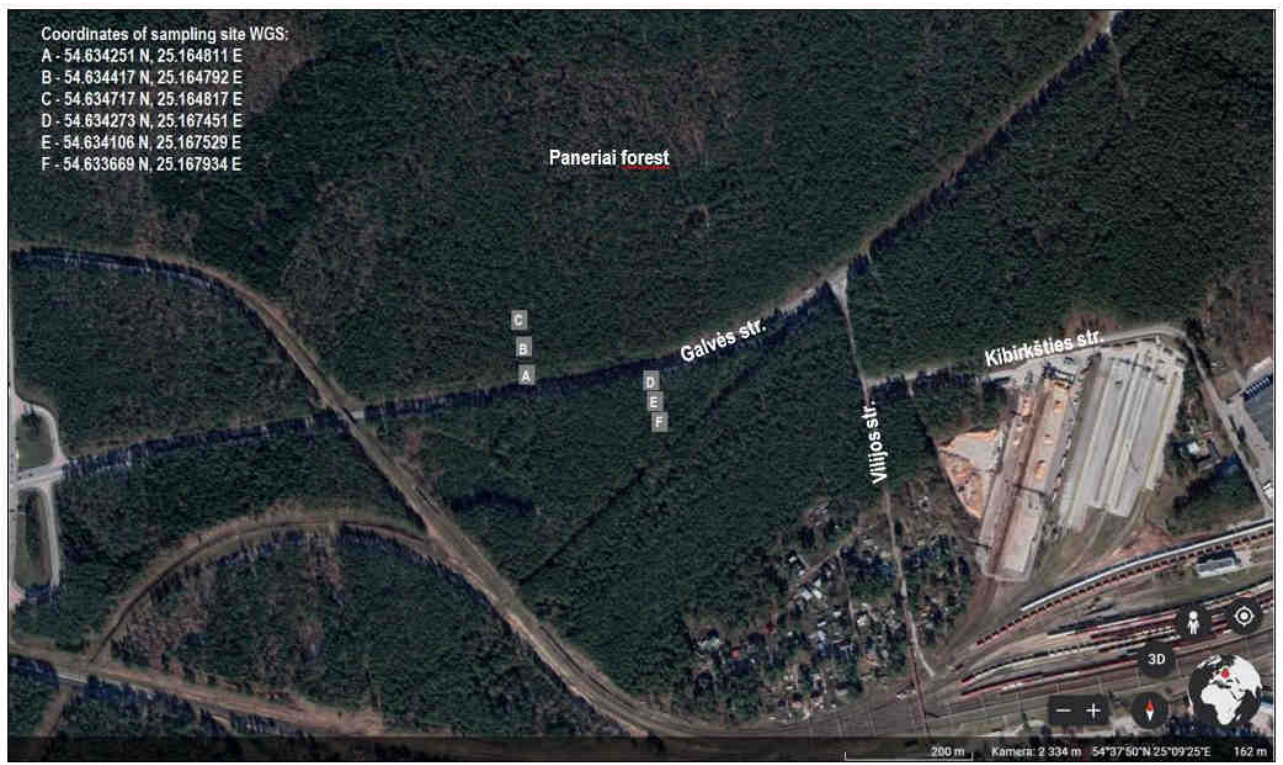

Fig. 1. Research places in Paneriai forest (A, B, C, D, E, F marked area corresponds to soil sampling sites) Vilnius

Conifers and a small amount of deciduous trees dominated in soil of sampling area. The research place of $\mathrm{A}$ and $\mathrm{D}$ areas were chosen in distance of few meters from the street, where dominated grass cover floor surface. In further areas from the road grass floor was changed by forest floor.

The more accurate principle of selection of sample areas is presented in the $2^{\text {nd }}$ example. The distance from both road sides was around 40-50 meters. This section was divided into three sections (measurement cells) (Fig. 2). The first measurement area was in distance of 1.5-2.0 meters from the street section. The second cell, representing the middle zone of pollution, was chosen to be around 10 meters from the first cell. The third measurement cell represented the neutral zone from the street and was in around 30 meters from the second cell. In every chosen cell, according to the "letter" principle, soil samples were taken at a depth of $0-30 \mathrm{~cm}$ in $10 \mathrm{~cm}$ intervals. 


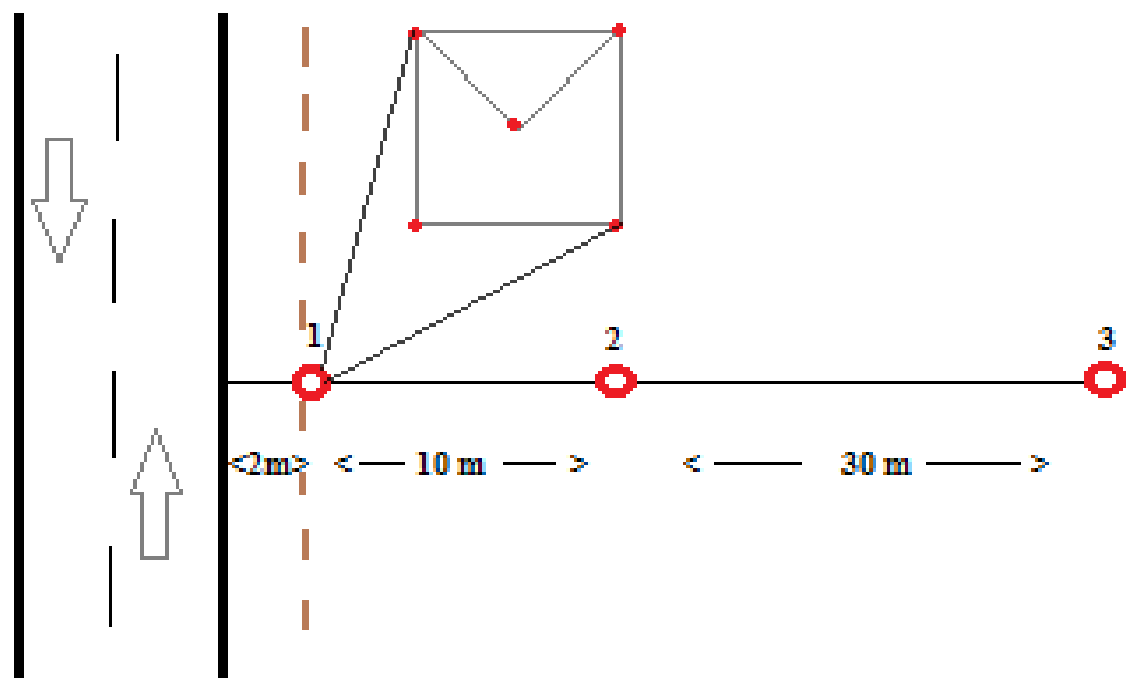

Fig. 2. Scheme of soil cells

The total organic carbon quantity in soil was determined with SSM-5000A. Before the analysis soil samples were chopped, riddled and dried in a laboratory oven at a temperature of $105 \pm 2{ }^{\circ} \mathrm{C}$ till stabile weight. Well dried soil samples were weighted with analytic scale. The sample was weighted when it was already put in a heated sample container [26]. The operation of device is based on incineration of a dry soil sample in a high temperature and assessing the released carbon dioxide quantity by an infrared light camera (Fig. 3).

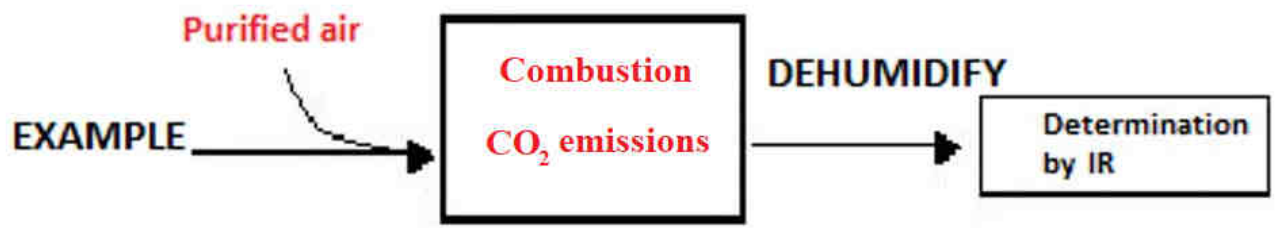

Fig. 3. Total organic carbon detection with Shimadzu SSM-5000A scheme

For the evaluation of carbon dioxide emission from soil ADC SRS-1000 device was used, which working principle is based on the absorption of infrared light (Fig. 4). The emission of carbon dioxide from soil was measured every hour in selected soil in order to fix a direct link with the atmosphere conditions.

Characteristics of ADC SRS-1000:

- $\quad \mathrm{CO}_{2}$ : up to 2000 ppm by integral elevated $\mathrm{CO}_{2}$ supply system;

- Infrared gas analyser $1 \mathrm{ppm}$ resolution;

- Flow rate to chamber: $0-500 \mathrm{~mL} \cdot \mathrm{min}^{-1}$. 


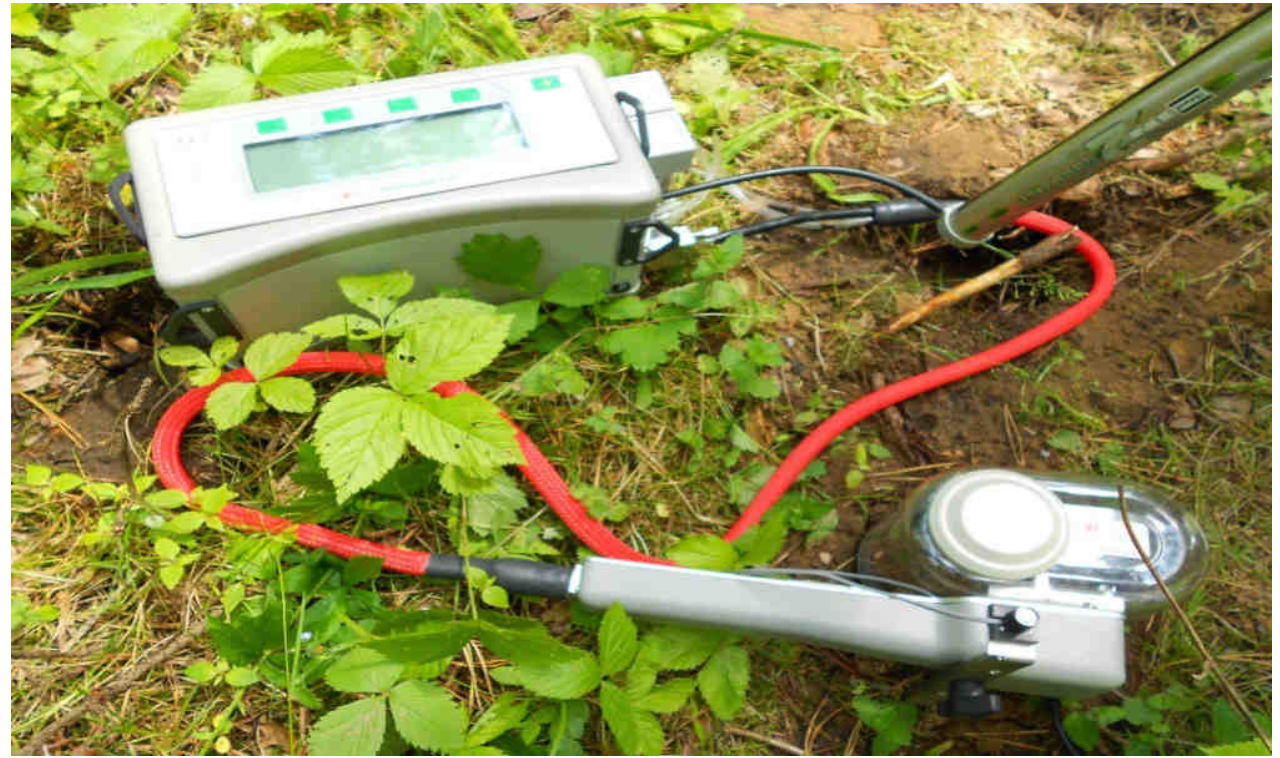

Fig. 4. ADC SRS-1000 for the measurements of $\mathrm{CO}_{2}$ emissions from the soil

An evaluation of HM (heavy metals) quantity in soil samples was carried out. The total content of HM in soil sample was analysed applying atomic absorption spectrometry (AAS) method. $10 \mathrm{~g}$ of soil sample was dried at $105 \pm 2{ }^{\circ} \mathrm{C}$ temperature till stabile weight. The dried soil sample was sieved through a $1 \mathrm{~mm}$ sieve and $1.0 \mathrm{~g}$ was digested in mixture of concentrated acids: $9 \mathrm{~mL}$ of $65 \%$ nitric acid and $3 \mathrm{~mL}$ of $36.5 \%$ hydrochloric acid. Duration of digestion was 1 hour. After soil digestion, a container with the sample was cooled down to the temperature of room. Then the solution was filtered through a $0.45 \mu \mathrm{m}$ glass filter into a $50 \mathrm{~mL}$ measuring flask. After filtration it was diluted with deionized water till the mark. These wavelengths were used for determination of heavy metal concentrations: $213.8 \mathrm{~nm}(\mathrm{Zn}) ; 232.0 \mathrm{~nm}(\mathrm{Ni}) ; 324.8 \mathrm{~nm}(\mathrm{Cu}) ; 283.3 \mathrm{~nm}(\mathrm{~Pb}) ; 358.0 \mathrm{~nm}$ (Cr). The atomic absorption spectrophotometer "Buck Scientific" 210 VGP was used for the heavy metal assessment in the soil. Graphite furnace was used for determination of $\mathrm{Pb}$ and $\mathrm{Cu}$ concentrations and acetylene-air flame was used for determination of $\mathrm{Zn}, \mathrm{Ni}$ and $\mathrm{Cr}$ concentrations. Concentrations of heavy metals in prepared samples were determined according to the LST ISO 11047:2004 standard. Concentration $C\left[\mathrm{mg} \cdot \mathrm{kg}^{-1}\right]$ of metal in solution was recalculated into concentration in soil applying formula:

$$
C=\frac{F \cdot V}{W}
$$

where: $F$ - concentration of metal in solution $\left[\mathrm{mg} \cdot \mathrm{L}^{-1}\right], V$ - final volume $(50 \mathrm{~mL})$ of solution, $W$ - initial weight $(1.0 \mathrm{~g})$ of sample measured.

\section{Quality assurance}

Standard solutions of heavy metals (1000 ppm) (Buck Scientific, USA) were used for FAAS or GFAAS calibration. All chemicals and reagents were of analytical grade or higher purity and were obtained from Sigma Aldrich (Germany) and were used in the experiments 
as received without further purification. The solutions were prepared by mixing standards in deionized water from the water purification system - Demiwa 3 roi (Watek, Czech Republic). Deionized water used in experiments meets the requirements of standard [27], electrical conductivity $<0.05 \mu \mathrm{S} / \mathrm{cm})$.

All volumetric flasks used in the experiments were soaked for $24 \mathrm{~h}$ in $5 \mathrm{M} \mathrm{HNO}_{3}$ and then rinsed 3-4 times carefully with deionized water. All the volumetric flasks were only the highest accuracy class. High accuracy analytical balance AS 60/220.R2 (Radwag, Poland) was used for weighting. Concentrated nitric (65\%) and hydrochloric (35\%) acids were used for the digestion of the samples (in "aqua regia"). In order to monitor for possible contaminations resulting from the sample preparation procedure, a reagent blank was prepared for each of the digestion procedure, following the entire sequence of steps as described above for sample preparation in each case. All experiments were conducted in triplicate and the mean of the three was calculated. Statistical analysis of data was carried out using Microsoft Excel software. Statistical parameters were estimated at $p<0.05$.

\section{Results and discussion}

Emissions of petroleum and its burning products has impact on total organic carbon quantity in the soil in area close to the used road section as well as vegetation period. The highest accumulation of total organic carbon was observed in meadow and forest surface soil layers in the late spring (May). These results were obtained due to the active vegetation period in this time and higher quantities of humus in the soil [28]. Total organic carbon content in the soil of forest (10 $\mathrm{m}$ from the street) is presented in Figure 5.

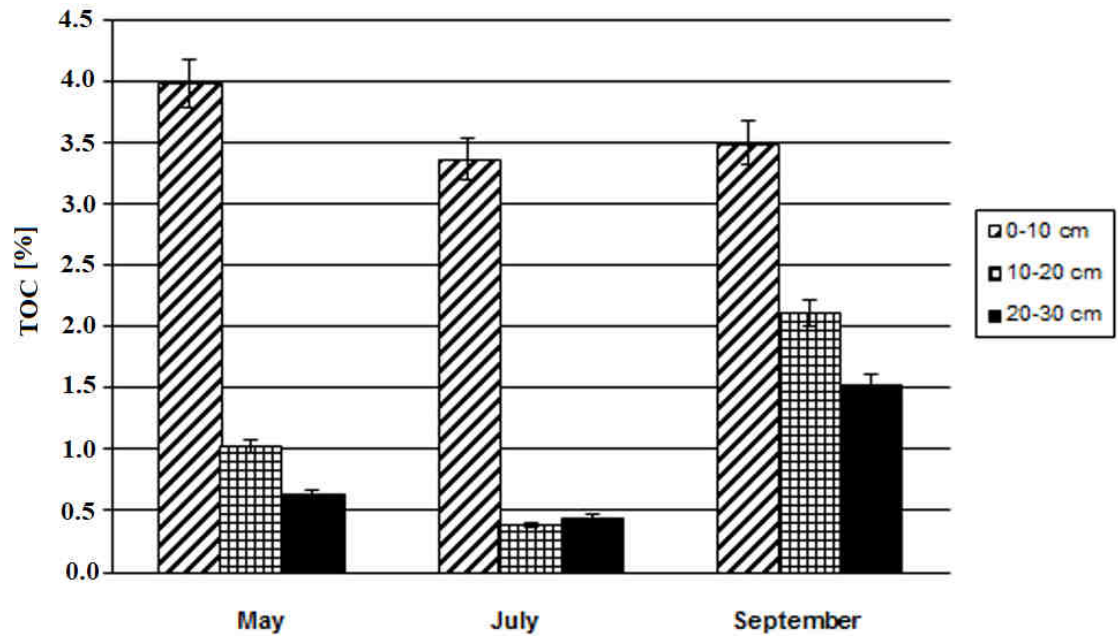

Fig. 5. Total organic carbon content in the soil of forest (10 $\mathrm{m}$ from the street)

According to the obtained results the tendency of significant total organic carbon content decreasing with increasing of soil depth was registered. This was especially evident in soil of transitional outskirts type where total organic carbon quantity was about 8 times lower than in the surface soil layer (3.369 and $0.442 \%$ accordingly) (Fig. 5) due to mold changes by sand in deeper layers of soil. Presented research of total organic carbon content 
in the outskirts type of soil in Figure 5 were conducted in the distance of 10 meters from the used street section at both its sides. The total organic carbon content in $0-10 \mathrm{~cm}$ depth of soil was $3.978 \%$ in May (Fig. 5). In the deeper soil layers it was significantly lower - it decreased to $1.02 \%(10-20 \mathrm{~cm})$ or to $0.632 \%(20-30 \mathrm{~cm})$.

Total organic carbon quantity dependence on soil $\mathrm{pH}$ (in the summer) is present in Figure 6.

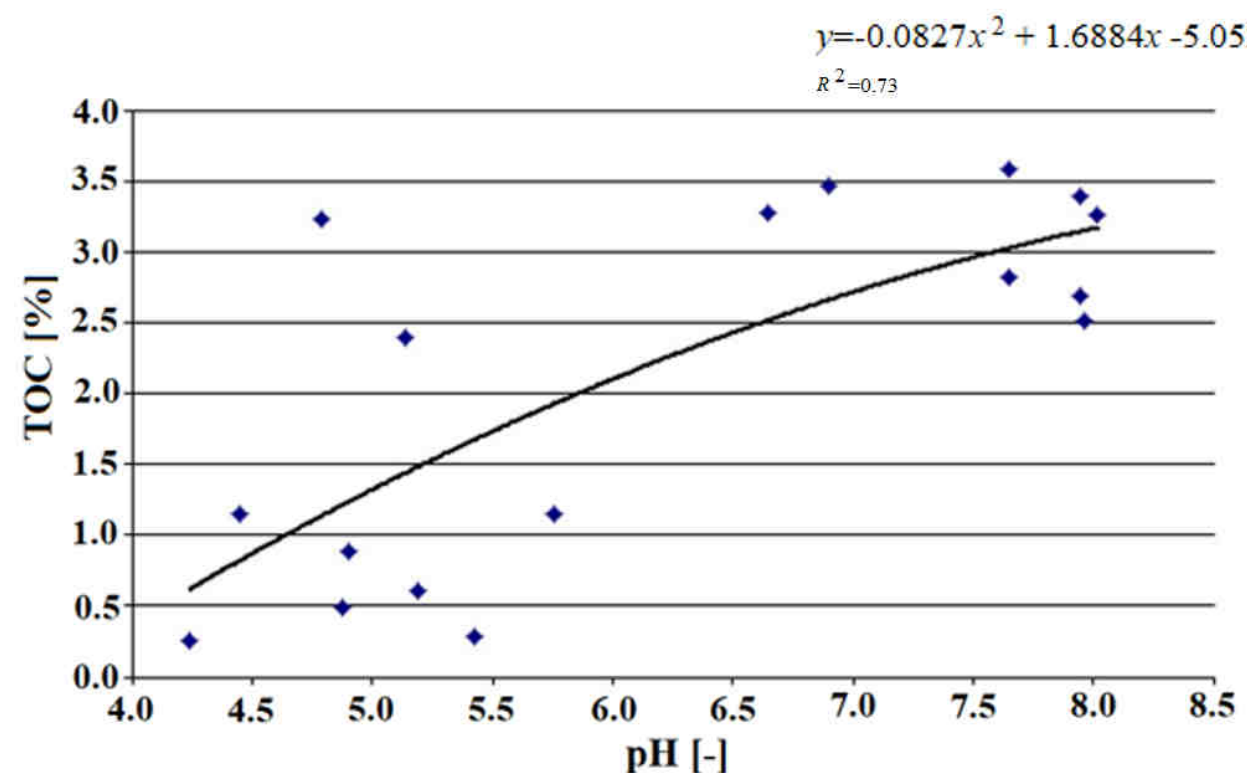

Fig. 6. Total organic carbon quantity dependence on soil $\mathrm{pH}$ (in the summer)

After conducting the experimental research of total organic carbon and $\mathrm{pH}$ of soil it was observed that at different selected seasons collected data from the research areas delivered very similar results. According to the obtained results when soil depth is increasing - total organic carbon quantity is decreasing. This is especially evident in transitional outskirt soil where total organic carbon quantity in accordance to the surface soil layer is 8 times lower (from 3.369 to $0.442 \%$ ). When soil pH increases, total organic carbon content increases too (Fig. 6). Under these conditions carbonate compounds are formed in alkaline soil and due to this reason total organic carbon content increases. This dependence is observed in collected soil samples from a summer time (correlation coefficient is 0.73) (Fig. 6). Minimum total organic carbon quantity was determined in more acidic soil, which according to the conducted research, is assigned to outskirt and forest samples. Of course, some impact was due to soil composition as sandy loam was observed at a depth of $15 \mathrm{~cm}$ and deeper, sand was observed in research areas in outskirt and in forest soil (Fig. 6).

Heavy metal concentrations and total organic carbon content in the soil at different distances from the kerbside (in May) is presented in Figure 7. 


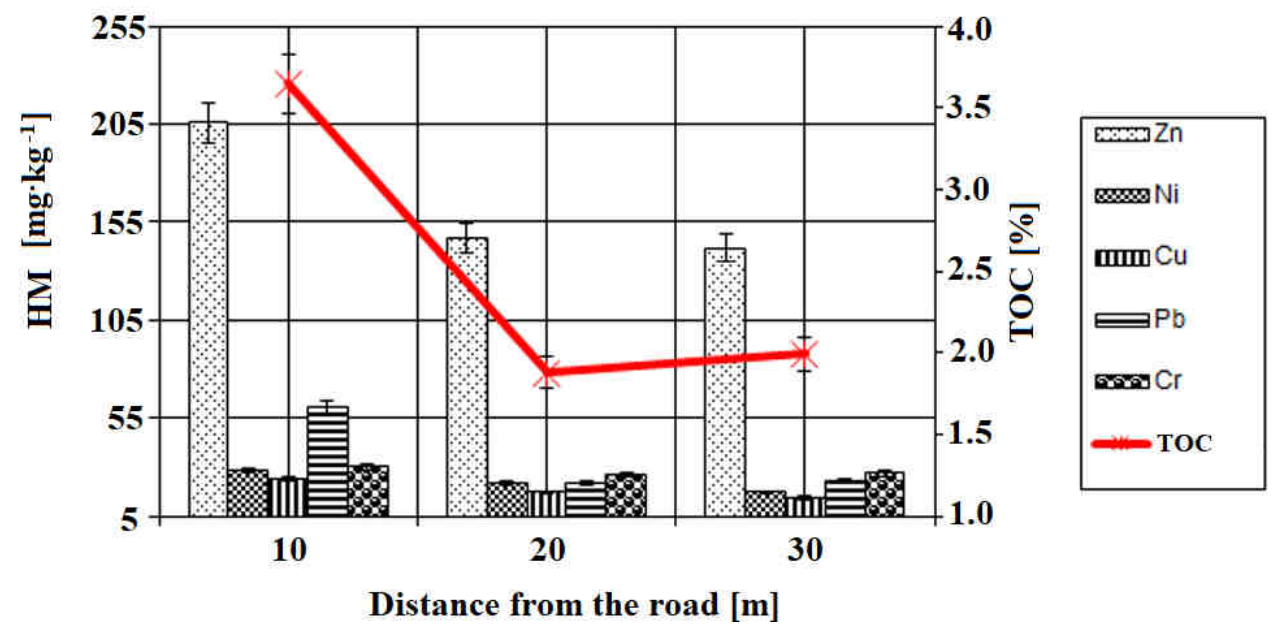

Fig. 7. Heavy metal (HM) concentrations and total organic carbon content in the soil at different distances from the kerbside (in May)

It was observed that heavy metals concentration in soil is affected by the distance from the used street section. When the distance increases, concentration of heavy metals in soil decreases and total organic carbon content decreases as well (Fig. 7). According to the experimental research data the highest concentration of zinc was registered among investigated heavy metals. The highest concentration of $\mathrm{Zn}\left(205.9 \mathrm{mg} \cdot \mathrm{kg}^{-1}\right)$ was measured in meadow soil close to the road in spring. This increasing could be explained by the impact of melted snow polluted with heavy metals closest to the used street section. In subsequent months zinc concentrations in soil slightly decreased. According to the Lithuanian hygienic norm (HN 60:2004), in the spring zinc concentration in soil did not exceed the limit value in light soil, however it was significantly higher than background values. Concentrations of other selected heavy metals $(\mathrm{Ni}, \mathrm{Cu}, \mathrm{Pb}$ and $\mathrm{Cr})$ in soil were smaller. Limit values for heavy metals concentration in soil are presented in Table 1 [29-31]. Background values of heavy metals $(\mathrm{Zn}, \mathrm{Cu}, \mathrm{Cr}$ and $\mathrm{Pb})$ concentration in soils are equal to $26,8.1,30$ and $15 \mathrm{mg} \cdot \mathrm{kg}^{-1}$ (sandy soil) according to Lithuanian normative [29].

Table 1

Limit values of heavy metals in soil

\begin{tabular}{|c|c|c|c|}
\hline $\begin{array}{c}\text { Heavy metals in dry } \\
\text { matter }\left[\mathbf{m g}^{*} \mathbf{k g}^{-\mathbf{1}} \text { ] }\right.\end{array}$ & $\begin{array}{c}\text { Lithuanian values for } \\
\text { heavy metals in soil [29] }\end{array}$ & $\begin{array}{c}\text { Norwegian values for } \\
\text { heavy metals in soil [30] }\end{array}$ & $\begin{array}{c}\text { Limit values for heavy } \\
\text { metals in soil of Europe [31] }\end{array}$ \\
\hline Lead $(\mathrm{Pb})$ & 100 & 60 & $50-300$ \\
\hline Copper $(\mathrm{Cu})$ & 100 & 100 & $50-140$ \\
\hline Chrome $(\mathrm{CrVI})$ & 100 & 2 & - \\
\hline Nickel $(\mathrm{Ni})$ & 75 & 60 & $30-75$ \\
\hline Zinc $(\mathrm{Zn})$ & 300 & 200 & $150-300$ \\
\hline
\end{tabular}

$\mathrm{CO}_{2}$ emissions from the soil during the day in forest soil, 10 meters from the street is presented in Figure 8. 


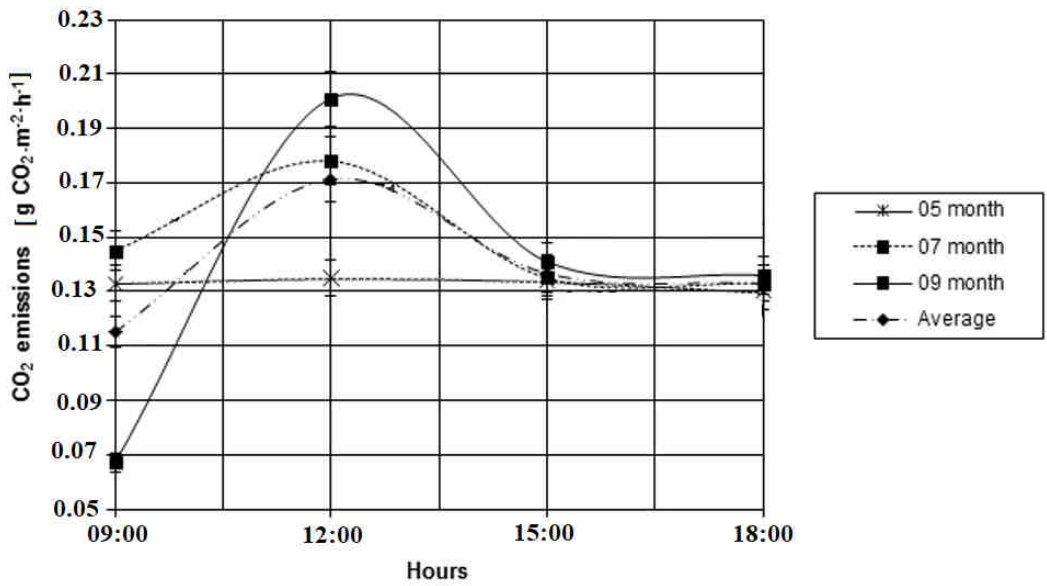

Fig. 8. $\mathrm{CO}_{2}$ emissions from the soil during the day in forest soil, 10 meters from the street

According to the obtained experimental data it was established that the most active $\mathrm{CO}_{2}$ emission from soil was registered in afternoon hours up to $0.201 \mathrm{~g} \mathrm{CO}_{2} \cdot \mathrm{m}^{-2} \cdot \mathrm{h}^{-1}$ (Fig. 8). In the morning was registered low emission of $\mathrm{CO}_{2}$, due to higher moisture both in air and soil, which prevents the emission of $\mathrm{CO}_{2}$. This increasing of $\mathrm{CO}_{2}$ emission was especially evident during conducted researches in September, when soil moisture was higher in the morning and decreases in the afternoon, and due to this $\mathrm{CO}_{2}$ emission from soil increases from $0.067 \mathrm{~g} \mathrm{CO}_{2} \cdot \mathrm{m}^{-2} \cdot \mathrm{h}^{-1}$ till $0.201 \mathrm{~g} \mathrm{CO}_{2} \cdot \mathrm{m}^{-2} \cdot \mathrm{h}^{-1}$.

Dependence between carbon dioxide emissions and soil temperature at different distances from the street is presented in Figure 9.

a)

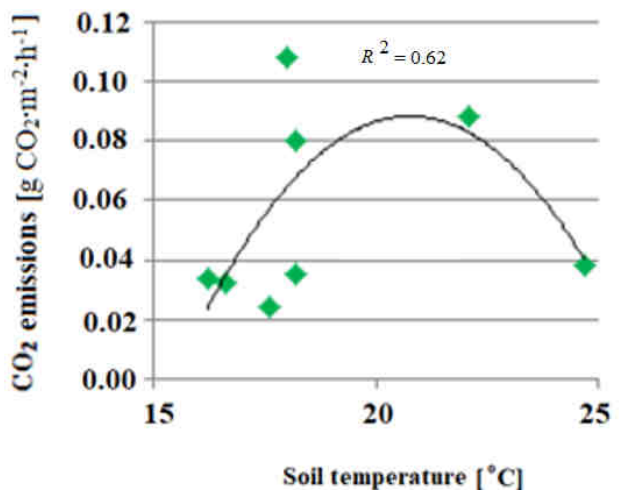

b)

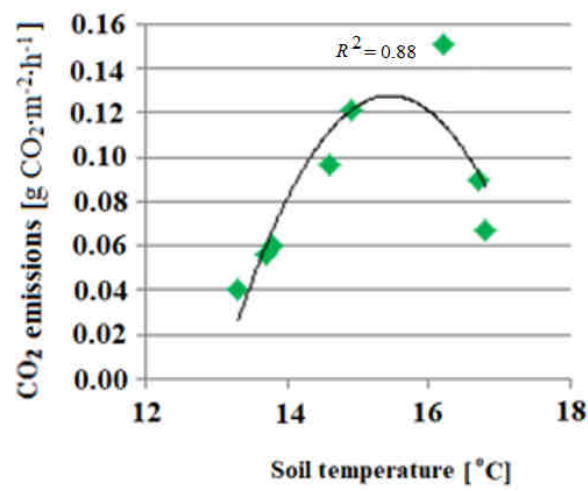

Fig. 9. Dependence between carbon dioxide emissions and soil temperature at different distances from the street: a) $2 \mathrm{~m}$ (grass cover), b) $30 \mathrm{~m}$ (forest soil)

Separately analysing changes of carbon dioxide emission from soil in every distance from the used street section, the very close dependence with soil temperature was observed. 
In all investigated distances from the street $\mathrm{CO}_{2}$ emissions increases with increasing of soil temperature. The strongest relationship between $\mathrm{CO}_{2}$ emission and temperature was observed in furthest distance from the street - in forest soil and correlation coefficient was equal to 0.88 (Fig. 9).

Dependence between carbon dioxide emissions and relative humidity of air at different distances from the street is presented in Figure 10.

a)

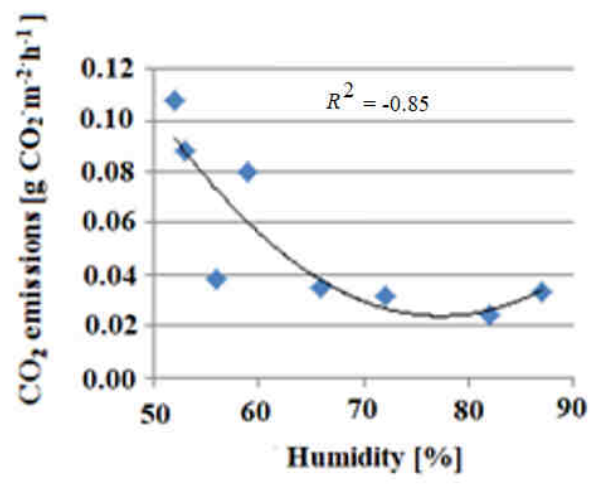

b)

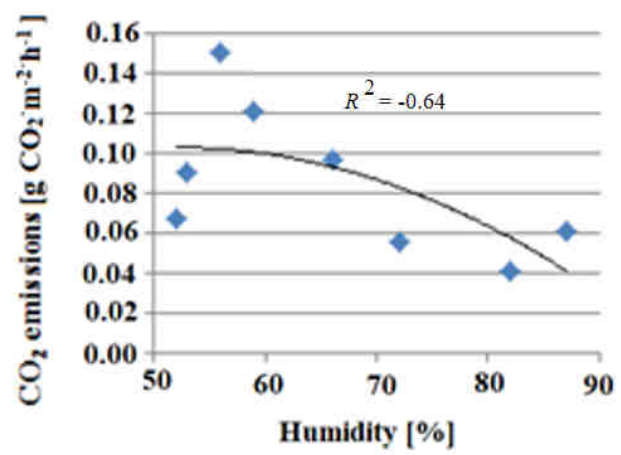

Fig. 10. Dependence between carbon dioxide emissions and relative humidity of air at different distances from the road: a) $2 \mathrm{~m}$ (grass cover), b) $30 \mathrm{~m}$ (forest soil)

Humidity of soil and water vapour content in the air has a decisive impact to $\mathrm{CO}_{2}$ emission from the soil. During analysis of the obtained data, it was observed that the change of carbon dioxide emission is closely connected to the air humidity (Fig. 10). Increasing of water vapour content in the air is the reason of $\mathrm{CO}_{2}$ emission decreasing. The strongest relationship was observed closest to the used street section ( $2 \mathrm{~m}$ distance). Correlation coefficient shows a strong negative relationship equal to -0.85 (Fig. 10). Excessive moisture prevents the activity of microorganisms, which reduces $\mathrm{CO}_{2}$ emission from the soil. Moreover, higher air turbulence was in the assessment points close to the street which without doubt contributed to the decreasing of this parameter.

\section{Conclusion}

1. Highest quantity of total organic carbon was observed in surface $(0-10 \mathrm{~cm})$ layer of soil. The highest quantity was accumulated in the outskirt and forest surface soil layer, in late spring.

2. According to the obtained results when soil depth is increasing - total organic carbon quantity is decreasing. This is especially evident in transitional outskirt soil where total organic carbon quantity in accordance to the surface soil layer is about 8 times lower (from 3.369 to $0.442 \%$ ).

3. It was observed that the collected soil from research areas in different time seasons delivered similar results according two parameters - total organic carbon and $\mathrm{pH}$. When carbonaceous compounds are accumulated in soil, e.g. when soil become more alkaline, quantity of total organic carbon is increasing in soil. 
4. It was observed that concentration of heavy metals in soil is affected by the distance from the used street section. When the distance is $2 \mathrm{~m}$ from the street, the concentration of $\mathrm{Zn}$ was $205.9 \mathrm{mg} \cdot \mathrm{kg}^{-1}$, which exceeds background values of this heavy metal. When the distance was $30 \mathrm{~m}$, concentration of zinc was $141.5 \mathrm{mg} \cdot \mathrm{kg}^{-1}$.

5. The most active $\mathrm{CO}_{2}$ emission is registered in afternoon hours and equals to $0.201 \mathrm{~g} \mathrm{CO}_{2} \cdot \mathrm{m}^{-2} \cdot \mathrm{h}^{-1}$. $\mathrm{CO}_{2}$ emission in the morning was especially low and was equal to $0.067 \mathrm{~g} \mathrm{CO}_{2} \cdot \mathrm{m}^{-2} \cdot \mathrm{h}^{-1}$. This low emission is affected by higher level of humidity both in the air and soil which prevents $\mathrm{CO}_{2}$ emission from the soil.

6. Carbon dioxide emissions is increasing with increasing of soil temperature. The strongest relationship was observed furthest from the used street section in the forest soil, correlation coefficient was equal to 0.88 .

7. Emission of carbon dioxide from the soil is closely related to the air humidity. With increasing of air humidity $\mathrm{CO}_{2}$ emission is decreasing. The strongest relationship was observed closest to the street section ( $2 \mathrm{~m}$ distance). Correlation coefficient showed a strong negative relationship, equal to 0.85 .

\section{References}

[1] Soil organic matter management across the EU - best practices, constraints and trade-offs. Available from: https://op.europa.eu/en/publication-detail/-/publication/c4826475-ab97-4375-941a-19ea8e5c8ef6.

[2] Pawłowska M, Pawlowski A, Pawlowski L, Cel W, Oliveira KW, Kwiatkowski C, et al. Ecol Chem Eng S. 2019;26(4):641-9. DOI: 10.1515/eces-2019-0046.

[3] Filak M, Hoffman S. Ecol Chem Eng S. 2020;27(4):567-78. DOI: 10.2478/eces-2020-0035.

[4] Daugela I, Visockiene JS, Skeivalas J. Analysis of air pollution parameters using covariance function theory. Ecol Chem Eng S. 2020;27(4):555-65. DOI: 10.2478/eces-2020-0034.

[5] Su-Ping H, Ma SZ, Pan Y, Li Y, Yu-Hsi Y, Tsai SB. Ecol Chem Eng S. 2020;27(1):55-66. DOI: 10.2478/eces-2020-0003.

[6] Korzeniowska J, Panek E. Ecol Chem Eng S. 2019;26(4):651-63. DOI: 10.1515/eces-2019-0047.

[7] Baltrènas P, Pranskevičius M, Lietuvninkas A. J Environ Eng Landsc Manage. 2010;18(3):179-187. DOI: 10.3846/jeelm.2010.21

[8] Motuzas A, Buivydaitė V, Vaisvalavičius R, Šleinys, RA. Soil science. Vilnius; Enciklopedija: 2009. pp. 335. ISBN: 9789986433491.

[9] Feizienè D, Feiza V. 2010. My farm. 4. Available from: http://www.manoukis.lt/?m=1\&s=2147\&z=96

[10] Marcinkonis S, Booth CA, Fullen MA, Tripolskaja L. Commun Soil Sci Plant Anal. 2011;42:1565-80. DOI: 10.1080/00103624.2011.581720.

[11] Liaudanskienė I, Šlepetienė A, Velykis A. Agriculture. 2011;98(3):227-34. Available from: http://193.219.178.8/tomai/98(3)tomas/98_3_tomas_str1.pdf.

[12] Karlberg L, Gustafsson D, Jansson PE. Ambio. 2006;35(8):448-58. DOI: 10.1579/0044-7447(2006)35[448:MCTIFT]2.0.CO;2.

[13] Kimble JM, Lal R, Follett RF. Assessment Methods for Soil Carbon. Boca Raton, FL: Lewis Publishers; 2001:3-12. DOI: 10.1201/9781482278644.

[14] Rutkowska B, Szulc W, Sosulski T, Skowrońska M, Szczepaniak J. Soil Tillage Res. 2018;180:21-8. DOI: 10.1016/j.still.2018.02.012.

[15] Moitinho MR, Padovan MP, Panosso AR, Teixeira DDB, Ferraudo AS, La Scala JrN. Soil Tillage Res. 2015;148:127-32. DOI: 10.1016/j.still.2014.12.012.

[16] McGowen EB, Sharma S, Deng S, Zhang H. Warren JG. Agric Environ Lett. 2018;3(1):1-5. DOI: 10.2134/ael2018.02.0008.

[17] Dossou-Yovo ER, Brueggemann N, Jesse N, Huat J, Ago EE, Agbossou EK. Soil Tillage Res. 2016;156:44-53. DOI: 10.1016/j.still.2015.10.001.

[18] Mohamed EM, El-Naggar AH, Usman AR, Al-Wabel M. Pedosphere. 2015;25(1):46-56. DOI: 10.1016/S1002-0160(14)60075-8.

[19] Mancinelli R, Marinari S, Brunetti P, Radicetti E, Campiglia E. Soil Tillage Res. 2015;152:39-51. DOI: 10.1016/j.still.2015.04.001.

[20] Guo N, Wang A, Degen AA, Deng B, Shang Z, Ding L, et al. Atmos Environ. 2018;174:92-8. DOI: 10.1016/j.atmosenv.2017.11.053. 
[21] Yang G, Wang M, Chen H, Liu L, Wu N, Zhu D, et al. Atmos Environ. 2017;152:323-9. DOI: 10.1016/j.atmosenv.2016.12.051.

[22] Lawrence DM, Koven CD, Swenson SC, Riley WJ, Slater AG. Environ Res Lett. 2015;10(9):094011. DOI: 10.1088/1748-9326/10/9/094011.

[23] Tavares RLM, de Souza ZM, Siqueira DS, La Scala Júnior N, Panosso AR, Campos MCC. Acta Agric Scand B. Soil Plant Sci. 2015;65(8):755-62. DOI: 10.1080/09064710.2015.1061048.

[24] Abdalla K, Chivenge P, Ciais P, Chaplot V. Biogeosciences. 2016;13:3619-33. DOI: 10.5194/bg-13-3619-2016.

[25] Oo AZ, Sudo S, Akiyama H, Win KT, Shibata A, Yamamoto A, et al. PLoS ONE. 2018;13(2):e0192235. DOI: 10.1371/journal.pone.0192235.

[26] Nishimura S, Yonemura S, Minamikawa K, Yagi K. J Geophys Res Biogeosci. 2015;120(1):63-76. DOI: 10.1002/2014JG002746.

[27] ISO 3996:1987. Water for analytical laboratory use - Specification and test methods. Available from: https://www.iso.org/obp/ui/\#iso:std:iso:3696:ed-1:v1:en.

[28] Pranskevičius M, Lietuvninkas A. 8th International Conference "Environmental Engineering", Environ Prot. 2011;(1):284-91. Available from: http://dspace.vgtu.lt/bitstream/1/893/1/284_291_Pranskevicius_others.pdf.

[29] HN 60:2004. Maximum permitted concentrations of hazardous chemical substances in soil. Available from: https://e-seimas.lrs.lt/portal/legalAct/lt/TAD/TAIS.228693.

[30] Ecological risk assessment of contaminated sites. 2012. Available from: https://www2.mst.dk/Udgiv/publications/2012/05/978-87-92903-12-9.pdf.

[31] Council Directive 86/278/EEC. On the protection of the environment, and in particular of the soil, when sewage sludge is used in agriculture. Available from: https://eur-lex.europa.eu/legalcontent/EN/ALL/?uri=CELEX:01986L0278-20090420. 